\title{
Kualitas Daging Sapi Bali dan Daging Sapi Wagyu yang Disimpan pada Suhu Dingin
}

\author{
(THE QUALITY OF BALI AND WAGYU BEEF AT THE COLD STORAGE)
}

\author{
Kadek Karang Agustina ${ }^{1 *}$, Sonia Citra Dewi Sembiring ${ }^{2}$, I Ketut Suada ${ }^{1}$ \\ ${ }^{1}$ Laboratorium Kesehatan Masyarakat Veteriner, Fakultas Kedokteran Hewan, Universitas \\ Udayana. Jalan PB. Sudirman Denpasar, Bali. \\ ${ }^{2}$ Dokter Hewan Praktek Mandiri, Jl. Binjai Km 8,5 No. 317 Kampung Lalang, Medan, \\ Sumatera Utara. \\ *Email:k.agustina@unud.ac.id
}

\begin{abstract}
ABSTRAK
Penelitian ini bertujuan untuk mengetahui kualitas daging sapi bali dan daging sapi Wagyu yang disimpan pada suhu $4^{\circ} \mathrm{C}$. Penelitian ini menggunakan rancangan acak lengkap pola faktorial. Parameter kualitas daging yang diteliti meliputi $\mathrm{pH}$, kadar air, daya ikat air (DIA) dan tekstur. Hasil penelitian menunjukkan bahwa nilai $\mathrm{pH}$ daging sapi Wagyu dan daging sapi bali mengalami peningkatan selama penyimpanan pada suhu dingin. Sementara kadar air, Daya Ikat Air dan tekstur kedua jenis daging ini mengalami penurunan. Perubahan yang signifikan terjadi pada pengamatan hari ke empat. Dapat disimpulkan bahwa penyimpanan daging sapi baik daging Wagyu maupun sapi bali pada suhu $4^{\circ} \mathrm{C}$ tidak efektif untuk jangka waktu lebih dari 3 hari.
\end{abstract}

Kata kunci: daging sapi bali; daging sapi Wagyu; kualitas

\begin{abstract}
This study aims were to determine the quality of bali beef and Wagyu beef stored at $4^{\circ} \mathrm{C}$. This study used a completely randomized factorial pattern design. Meat quality parameters studied included $\mathrm{pH}$, water content, water holding capacity and texture. The results showed that the $\mathrm{pH}$ value of Wagyu beef and bali beef increased during storage at cold temperatures. While the water content, water binding capacity and texture of both types of meat has decreased. Significant changes occured in observations of the fourth day. It can be concluded that storage of Wagyu and bali beef at $4{ }^{\circ} \mathrm{C}$ was not effective for a period of more than 3 days.
\end{abstract}

Keywords: bali beef; Wagyu beef; qualities

\section{PENDAHULUAN}

Sapi merupakan ternak penghasil daging yang banyak dibudidayakan diberbagai negara (Widiati, 2014). Salah satu jenis daging sapi yang diperdagangkan secara internasional adalah daging sapi Wagyu (Smith, 2015). Diketahui daging sapi Wagyu memiliki keunggulan citarasa dengan kandungan marbling yang cukup tinggi pada dagingnya (Radunz et al., 2009; Smith, 2015). Sementara daging sapi lokal Indonesia yang banyak diperdangkan adalah daging sapi bali (Handiwirawan dan Subandriyo, 2004; Suwiti et al., 2017).
Daging sapi merupakan salah satu sumber protein hewani yang paling disukai oleh konsumen. Daging sapi mengandung sekitar $75 \%$ air, sekitar $19 \%$ protein, substansi-substansi nonprotein yang larut sebanyak 3,5\% serta lemak sekitar 2,5\%. Setiap 100 gr daging dapat memenuhi kebutuhan zat gizi satu orang dewasa setiap harinya sekitar $10 \%$ kalori, $50 \%$ protein dan $35 \%$ zat besi (Fe) (Lawrie, 2003). Komposisi kimia daging terdiri dari air $56 \%$, protein $22 \%$, lemak $24 \%$, dan substansi bukan protein terlarut $3,5 \%$ yang meliputi karbohidrat, garam organik, subtansi nitrogen terlarut, mineral, dan 
vitamin. Daging merupakan bahan makanan yang penting dalam memenuhi kebutuhan gizi, selain mutu proteinnya yang tinggi, pada daging terdapat pula kandungan asam amino essensial yang lengkap dan seimbang (Pereira and Vicente, 2013).

Penyimpanan pada suhu rendah telah lama digunakan sebagai salah satu cara penyimpanan bahan pangan segar, karena dapat mempertahankan citarasa dan menghambat kerusakan bahan pangan tersebut (Prasetyo dan Kendriyanto, 2010). Pendinginan dapat memperlambat kecepatan reaksi metabolisme keaktifan respirasi sehingga pertumbuhan bakteri dan kebusukan dapat dihambat. Semakin rendah suhu lingkungan, aktifitas enzim menjadi semakin berkurang. Istilah penyimpanan dingin biasanya diartikan sebagai penggunaan suhu rendah dalam kisaran 10 sampai $4^{\circ} \mathrm{C}$, suhu yang jauh melebihi permulaan pembekuan otot, tetapi masih berada dalam suhu optimum $-2^{\circ} \mathrm{C}$ dan $7^{\circ} \mathrm{C}$ bagi pertumbuhan organisme psikrofilik (Ballin, 2010).

\section{MATERI DAN METODE}

\section{Sampel}

Penelitian ini menggunakan sampel daging sapi bali dan daging sapi Wagyu yang diperoleh di pasar swalayan diwilayah Kabupaten Badung Bali.

\section{Metode pemeriksaan}

Penelitian ini menggunakan Rancangan Acak Lengkap (RAL) pola faktorial $2 \times 6$ yaitu 2 faktor jenis daging (Wagyu dan sapi bali) dengan 6 lama penyimpanan pada suhu dingin $4^{\circ} \mathrm{C}$ yaitu 0 hari, 1 hari, 2 hari,
3 hari, 4 hari dan 5 hari. Setiap kombinasi perlakuan penelitian diulang sebanyak 3 kali. Perubahan yang diamati pada penelitian ini meliputi $\mathrm{pH}$, kadar air, daya ikat air dan tekstur. Nilai $\mathrm{pH}$ ditetapkan dengan menggunakan alat $\mathrm{pH}$ meter, kadar air menggunakan metode oven, sementara Daya Ikat Air dengan metode Hamm (Swacita dan Suardana, 2008).

\section{Analisis data}

Data hasil pemeriksaan ditabulasi dan dianalisis ragam dan dilanjutkan dengan uji Duncan untuk menentukan perbedaan kualitas dimasing masing kombinasi perlakuan pada daging sapi bali maupun daging Wagyu (Sarassati dan Agustina, 2015).

\section{HASIL DAN PEMBAHASAN}

Tabel 1 menunjukkan bahwa terjadi peningkatan nilai $\mathrm{pH}$ pada kedua jenis daging yang nyata $(\mathrm{P}<0,05)$ pada penyimpanan hari ke 4 . Nilai $\mathrm{pH}$ otot saat hewan hidup sekitar 7,0-7,2 (Hopkins et al., 2014). Setelah hewan disembelih nilai $\mathrm{pH}$ daging akan menurun akibat adanya akumulasi asam laktat. Penurunan nilai $\mathrm{pH}$ pada otot hewan yang sehat dan ditangani dengan baik sebelum pemotongan akan berjalan secara bertahap, yaitu dari nilai $\mathrm{pH}$ sekitar 7,0-7,2 akan mencapai nilai $\mathrm{pH}$ menurun secara bertahap dari 7,0 sampai 5,6-5,7 dalam waktu 6-8 jam postmortem dan akan mencapai nilai $\mathrm{pH}$ akhir sekitar 5,5-5,6 (Weglarz, 2010). Nilai pH ultimate adalah nilai $\mathrm{pH}$ terendah yang dicapai pada otot setelah pemotongan (Gebrehiwot et al., 2018).

Tabel 1 . Hasil uji Duncan nilai $\mathrm{pH}$ daging sapi pada penyimpanan $4^{\circ} \mathrm{C}$

\begin{tabular}{ccc}
\hline Lama Simpan & \multicolumn{2}{c}{ Daging } \\
\cline { 2 - 3 } Pada Suhu $4^{\circ} \mathrm{C}($ Hari $)$ & Wagyu & Sapi Bali \\
\hline 0 & $5,43 \pm 0,02^{\mathrm{a}}$ & $5,57 \pm 0,02^{\mathrm{a}}$ \\
1 & $5,47 \pm 0,02^{\mathrm{a}}$ & $5,57 \pm 0,02^{\mathrm{a}}$ \\
2 & $5,51 \pm 0,02^{\mathrm{a}}$ & $5,58 \pm 0,02^{\mathrm{a}}$ \\
3 & $5,53 \pm 0,01^{\mathrm{a}}$ & $5,59 \pm 0,01^{\mathrm{a}}$ \\
4 & $5,54 \pm 0,01^{\mathrm{b}}$ & $5,66 \pm 0,05^{\mathrm{b}}$ \\
5 & $5,57 \pm 0,02^{\mathrm{b}}$ & $5,64 \pm 0,03^{\mathrm{b}}$ \\
\hline
\end{tabular}

Ket: huruf yang sama menandakan tidak berbeda nyata $(\mathrm{P}>0,05)$, huruf yang berbeda menunjukkan berbeda nyata $(\mathrm{P}<0,05)$. 
Tabel 2. Hasil uji Duncan kadar air daging sapi Wagyu dan daging sapi bali pada penyimpanan $4^{\circ} \mathrm{C}$

\begin{tabular}{ccc}
\hline Lama Simpan & \multicolumn{2}{c}{ Daging } \\
\cline { 2 - 3 } Pada Suhu 4 $\mathrm{C}$ (Hari) & Wagyu & Sapi Bali \\
\hline 0 & $60.5 \pm 0,41^{\mathrm{a}}$ & $76,4 \pm 0,52^{\mathrm{a}}$ \\
1 & $59,4 \pm 0,28^{\mathrm{a}}$ & $75,7 \pm 0,43^{\mathrm{b}}$ \\
2 & $58,2 \pm 0,31^{\mathrm{b}}$ & $75,2 \pm 0,17^{\mathrm{b}}$ \\
3 & $57,5 \pm 0,26^{\mathrm{b}}$ & $74,2 \pm 0,39^{\mathrm{c}}$ \\
4 & $56,2 \pm 0,44^{\mathrm{c}}$ & $73,4 \pm 0,35^{\mathrm{c}}$ \\
5 & $54,3 \pm 1,06^{\mathrm{d}}$ & $72,4 \pm 0,13^{\mathrm{d}}$ \\
\hline
\end{tabular}

Ket: huruf yang sama menandakan tidak berbeda nyata $(\mathrm{P}>0,05)$, huruf yang berbeda menunjukkan berbeda nyata $(\mathrm{P}<0,05)$.

Tabel 3. Hasil uji Duncan daya ikat air daging sapi Wagyu dan daging sapi pada penyimpanan $4^{\circ} \mathrm{C}$

\begin{tabular}{ccc}
\hline Lama Simpan & \multicolumn{2}{c}{ Daging } \\
\cline { 2 - 3 } Pada Suhu $4^{\circ} \mathrm{C}($ Hari $)$ & Wagyu & Sapi Bali \\
\hline 0 & $64,0 \pm 0,57^{\mathrm{a}}$ & $67,1 \pm 0,11^{\mathrm{a}}$ \\
1 & $62,1 \pm 0,23^{\mathrm{b}}$ & $65,3 \pm 0,57^{\mathrm{b}}$ \\
2 & $60,8 \pm 0,34^{\mathrm{c}}$ & $65,0 \pm 0,34^{\mathrm{b}}$ \\
4 & $60,4 \pm 0,41^{\mathrm{c}}$ & $63,7 \pm 0,80^{\mathrm{c}}$ \\
5 & $60,1 \pm 0,23^{\mathrm{c}}$ & $63,6 \pm 0,52^{\mathrm{c}}$ \\
\hline
\end{tabular}

Ket: huruf yang sama menandakan tidak berbeda nyata $(\mathrm{P}>0,05)$, huruf yang berbeda menunjukkan berbeda nyata $(\mathrm{P}<0,05)$.

Tabel 4. Hasil uji Duncan tekstur daging sapi Wagyu dan daging sapi bali pada Penyimpanan $4^{\circ} \mathrm{C}$

\begin{tabular}{ccc}
\hline Lama Simpan & \multicolumn{2}{c}{ Daging } \\
\cline { 2 - 3 } Pada Suhu $4^{\circ} \mathrm{C}$ (Hari) & Wagyu & Sapi Bali \\
\hline 0 & $3,8 \pm 0,57^{\mathrm{a}}$ & $2,8 \pm 0,57^{\mathrm{a}}$ \\
1 & $3,8 \pm 0,57^{\mathrm{b}}$ & $2,5 \pm 0,57^{\mathrm{b}}$ \\
2 & $3,8 \pm 0,57^{\mathrm{b}}$ & $2,2 \pm 0,57^{\mathrm{c}}$ \\
4 & $3,2 \pm 0,57^{\mathrm{c}}$ & $2,0 \pm 0,57^{\mathrm{d}}$ \\
5 & $3,0 \pm 0,57^{\mathrm{d}}$ & $1,6 \pm 0,57^{\mathrm{e}}$ \\
\hline
\end{tabular}

Ket: huruf yang sama menandakan tidak berbeda nyata $(\mathrm{P}>0,05)$, huruf yang berbeda menunjukkan berbeda nyata $(\mathrm{P}<0,05)$.

Hasil pemeriksaan kadar air daging sapi Wagyu dan daging sapi bali pada penyimpanan suhu dingin $4^{\circ} \mathrm{C}$ mengalami penurunan (Tab 2). Kadar air daging sapi bali diketahui lebih tinggi dibandingkan daging sapi Wagyu. Adanya perbedaan kadar air daging dapat dipengaruhi oleh kandungan lemak intramuskular, apabila kadar lemak daging meningkat, akan menyebabkan penurunan kadar air (Albrecht et al., 2011). Kadar air otot daging sering mempunyai hubungan negatif yang signifikan dengan kadar lemak daging (Harper and Pethick, 2004; Agustina et al., 2017). Daging sapi Wagyu merupakan jenis daging yang kaya akan kandungan marbling, yang menjadikannya daya tarik bagi konsumen (Hwang et al., 2010). Marbling akan memberikan aroma dan juice daging saat dimasak sehingga memiliki citarasa yang khas (Horii et al., 2009; Gotoh and Joo, 2016). 
Hasil pemeriksaan daya ikat air daging sapi Wagyu dan daging sapi bali pada penyimpanan suhu dingin $4^{\circ} \mathrm{C}$ mengalami penurunan (Tab 3). Semakin lama penyimpanan, maka semakin rendah daya ikat air (Lonergan and Lonergan, 2005). Besar kecilnya daya ikat air berpengaruh terhadap warna, keempukan, kekenyalan, juicness dan tekstur daging sapi (Gebrehiwot et al., 2018). Besar penurunan $\mathrm{pH}$ juga mempengaruhi daya ikat air dan makin tinggi $\mathrm{pH}$ akhir maka daya ikat air daging semakin menurun jika disimpan pada suhu dingin (Hopkins et al., 2014).

Hasil pemeriksaan uji tekstur daging sapi Wagyu dan daging sapi bali pada penyimpanan suhu $4^{\circ} \mathrm{C}$ mengalami penurunan (Tab 4). Hal ini terkait dengan penurunan kadar air daging yang akan meningkatkan proporsi padatan dan kekompakan dari stuktur bahan pangan, sehingga menyebabkan tekstur menjadi mengeras jika disimpan pada suhu dingin dalam waktu yang lama (Barrett et al., 1998). Tekstur menunjukkan ukuran ikatan-ikatan serabut otot yang dibatasi oleh septum-septum perimiseal jaringan ikat yang membagi otot secara longitudinal. Tekstur otot dibagi menjadi dua kategori, tekstur kasar dengan ikatan-ikatan serabut yang besar dan tekstur halus ikatan-ikatan serabut yang kecil. Ukuran suatu ikatan serabut otot ditentukan oleh jumlah serabut, ukuran serabut, dan jumlah perimisium yang mengelilingi dan menyelimuti setiap ikatan serabut otot (Sasaki et al., 2010)

\section{SIMPULAN}

Nilai pH daging sapi Wagyu maupun daging sapi bali mengalami peningkatan pada penyimpanan suhu $4^{\circ} \mathrm{C}$, sementara kadar air, Daya Ikat Air maupun teksturnya mengalami penurunan. Penyimpanan pada suhu $4^{\circ} \mathrm{C}$ dapat mempertahankan kesegaran daging sapi selama 3 hari.

\section{UCAPAN TERIMAKSIH}

Penulis mengucapkan terimakasih kepada Laboratorium Kesehatan Masyarakat Veteriner Fakultas Kedokteran
Hewan Universitas Udayana yang telah memfasilitasi penelitian ini.

\section{DAFTAR PUSTAKA}

Agustina KK, Cahya IMRD, Widyantara GM, Swacita IBN, Dharmayudha AAGO, Rudyanto MD. 2017. Nilai Gizi dan Kualitas Fisik Daging Sapi Bali berdasarkan Jenis Kelamin dan Umur. Bul. Vet. Udayana., 9(2): 156-163.

Albrecht E, Gotoh T, Ebara F, JX Xu, Viergutz T, Nuernberg G, Maak S, Wegner J. 2011. Cellular conditions for intramuscular fat deposition in Japanese Black and Holstein steers. Meat Sci., 89: 13-20.

Barrett A, Jack B, R. Mhicelle R, Timoty R. 1998. Texture and Storage Stability of Process Beefstick as Affected by Glycerol and Moisture Levels. J. Food Sci., 63: 84-87.

Ballin NZ. 2010. Authentication of meat and meat products. Meat Sci., 86(3): 577-587.

Gebrehiwot HW, Balcha E, Hagos Y, Wrkelul K. 2018. Determination of $\mathrm{pH}$ and water holding capacity of beef from selected butcher shops of Mekelle, Ethiopia. J. Vet. Med. Anim. Health., 10(6): 159-164.

Gotoh T, Joo ST. 2016. Characteristics and Health Benefit of Highly Marbled Wagyu and Hanwoo Beef. Korean J. Food Sci. Anim. Resour., 36(6): 709718.

Handiwirawan E, Subandriyo. 2004. Potensi dan Keragaman Sumberdaya Genetik Sapi Bali. Bogor. Bul. Ilmu Peternakan Indoesia., 14(3): 107-115.

Harper GS, Pethick DW. 2004. How might marbling begin? Australian J. Exp. Agric., 44(7): 653-662.

Hopkins DL, Ponnampalam EN, van de Ven RJ, Warner RD. 2014. The effect of $\mathrm{pH}$ decline rate on the meat and eating quality of beef carcasses. Anim. Prod. Sci., 54: 407-413.

Horii H, Sakurai Y, Kanbe Y, Kasai K, Ono $\mathrm{K}$, Asada T, Mori T, Kobayashi M, Iguchi A, Yamada M, Hayashi M, 
Hodate K. 2009. Relationship between Japanese beef marbling standard numbers and intramuscular lipid in $\mathrm{M}$. longissimus thoracis of Japanese Black steers from 1996 to 2004. Nihon Chikusan Gakkaiho., 80: 55-61.

Hwang YH, Kim GD, Jeong JY, Hur SJ, Joo ST. 2010. The relationship between muscle fiber characteristics and meat quality traits of highly marbled Hanwoo (Korean native cattle) steers. Meat Sci., 86: 456-461.

Judge MD, Arberle ED, Forrest JC, Hendrick HB, Merkel RA. 1989. Priciples Meat Science $2^{\text {nd }}$ Ed. Kendall/Hunt Publishing Co, lowa.

Lawrie RA. 2003. Ilmu Daging. Edisi 5 Penerjemah Aminuddin parakkasi. Penerbit Universitas Indonesia, Jakarta.

Lonergan EH, Lonergan SM. 2005. Mechanisms of water-holding capacity of meat. Meat Sci., 71: 194-204.

Pereira PMCC, Vicente AFRB. 2013. Meat nutritional composition and nutritive role in the human diet. Meat Sci., 93: 586-592.

Prasetyo A, Kendriyanto. 2010. Kualitas daging sapi dan domba segar yang disimpan pada suhu dingin dengan pengawet asap cair. Seminar Nasional Teknologi Peternakan dan Veteriner. Proc. Pp. 843-848.

Radunz AE, Loerch SC, Lowe GD, Fluharty FL, Zerby HN. 2009. Effect of Wagyu- versus Angus-sired calves on feedlot performance, carcass characteristics, and tenderness. J. Anim. Sci., 87(9): 2971-2976.
Sarassati T, Agustina KK. 2015. Kualitas Daging Sapi Wagyu dan Daging Sapi Bali yang Disimpan pada Suhu $-19^{\circ} \mathrm{C}$. Indon. Med. Vet., 4(3): 178-185.

Sasaki K, Motoyama M, Yasuda J, Yamamoto $T$, Oe $M$, Narita $N$, MaiImanari, Fujimura S, Mitsumoto M. 2010. Beef texture characterization using internationally established texture vocabularies in ISO5492:1992: Differences among four different endpoint temperatures in three muscles of Holstein steers. Meat Sci., 86(2): 422429.

Smith SB. 2015. The Production of HighQuality Beef with Wagyu Cattle. Texas A\&M University Department of Animal Science College Station, TX 77843-2471. Pp: 1-26

Suardana IW, Swacita IBN. 2009. Higiene Makanan. Udayana University Press. Denpasar.

Suwiti NK, Besung INK, Mahardika GN. 2017. Factors influencing growth hormone levels of Bali cattle in Bali, Nusa Penida, and Sumbawa Islands, Indonesia. Vet. World., 10(10): 12501254.

Weglarz A. 2010. Meat quality defined based on $\mathrm{pH}$ and colour depending on cattle category and slaughter season. Czech J. Anim. Sci., 55(12): 548-556.

Widiati R. 2014. Membangun Industri Peternakan Sapi Potong Rakyatdalam Mendukung KecukupanDaging Sapi. Wartazoa., 24(4): 191-200. 